\title{
SUSTAINABLE MANAGEMENT, BALANCED SCORECARD AND SMALL BUSINESS: A SYSTEMATIC REVIEW AND STATE OF THE
}

ART

\author{
Marileide Barbosa \\ Pontifícia Universidade Católica de Campinas, Brazil \\ E-mail: barbosa.marileide@gmail.com \\ Juan Arturo Castañeda-Ayarza \\ Pontifícia Universidade Católica de Campinas, Brazil \\ E-mail: juan.arturo@puc-campinas.edu.br \\ Denise Helena Lombardo Ferreira \\ Pontifícia Universidade Católica de Campinas, Brazil \\ E-mail: lombardo@puc-campinas.edu.br
}

Submission: 2/1/2019

Revision: 2/15/2019

Accept: 5/17/2019

\section{ABSTRACT}

The Balanced Scorecard - BSC is a widely used tool in business management that allows implementing and controlling strategies. Today, in a context that demands efforts from all organizations for sustainable development, the BSC has become an excellent alternative to include sustainability in business management. However, when it comes to small business organizations, management tools like BSC and business sustainability face the greatest difficulties, barriers and limitations. Therefore, the objective is to map the frontier of knowledge that brings together sustainable management and BSC to small companies, allowing visualization of the paths covered and the ones to be taken through science. A systematic bibliographical research was developed identifying and analyzing the main scientific publications that intersect the themes mentioned above. The results show the need to increase research towards understanding and monitoring the transformation of small business management in terms of sustainable development. The importance of the use of management tools to improve the efficiency and effectiveness of the whole process has been confirmed, as well as that the BSC can play a relevant role. Thus, with this, researchers are expected to be more interested in the subject and more studies applied in small companies will come to be. 
DOI: 10.14807/ijmp.v11i1.1002

Keywords: sustainability; small business; Balanced Scorecard; SBSC; sustainable management

\section{INTRODUCTION}

The need for human society to rethink its development model based on the principles of sustainability reached the operational and administrative processes of organizations, requiring changes in the management model.

Sustainable management is understood as the adoption of actions that seek to meet the needs of the organization and all of its stakeholders. These actions seek to making a company, at the same time profitable, socially responsible and also concerned with the preservation of the natural physical environment with which it interacts (FIGGE et al., 2002; FALLE et al., 2016).

Tools used in specific areas of sustainable management can bring benefits to the entire company. For example, in environmental sustainability, tools like carbon foot print analysis, when applied through integrated practices, can improve the productive process, the performance of the entire company and also to improve the individual awareness and skills of employees, in addition to the positive impacts on the organization and environment relationship (AKHTAR et al., 2018; GIAMA; PAPADOPOULOS, 2018).

Thus, it can be understood that there is no single method for guiding he management of an organization into sustainability, since the process can be influenced by the type and size of the organization, the organizational environments, the goals and perspectives of the company. The greatest challenge lies in making ever-balanced decisions between economic, social and environmental issues (NAWAZ; KOÇ, 2018).

It is understood from Kaplan and Norton (2004) and Chalmeta and Palomero (2011) that in a globalized and highly competitive scenario, sustainability in organizations can be seen as an alternative for business growth, efficiency and effectiveness of sustainable actions, from the financial and non-financial perspectives.

Several researchers, such as Figge et al. (2002), Chalmeta and Palomero (2011), Hansen and Schaltegger (2012), Cantele and Zardini (2018) have contributed to studies for the management of sustainability in companies. In this sense, it is understood that the Balanced Scorecard (BSC), an implementation and strategic control tool, can be a promising alternative, especially for small companies, which have a major participation in the economic activity. 
DOI: 10.14807/ijmp.v11i1.1002

For example, in Brazil, small companies accounted for $72 \%$ of the jobs created in the country, registering a positive balance for four consecutive years, from 2014 to 2017. In 2017, 83.5 thousand jobs were generated by small business, compared to 31.4 thousand jobs generated by medium and large companies (SEBRAE, 2018).

Despite the importance of small companies, among all organizations they are the ones that present the most difficulty to develop professional management and, even more, to operationalize sustainable strategies, either because of a lack of technical knowledge, skills or resources (DEPKEN; ZEMAN, 2017).

Given this scenario, we identified the opportunity to map the frontier of scientific knowledge developed at the intersection of issues related to sustainable management, small business and the Balanced Scorecard management tool.

This paper follows the following structure: Section 2 is devoted to the theoretical framework on sustainability in small companies, the Balanced Scorecard (BSC) and the Sustainable Balanced Scorecard (SBSC). Section 3 deals with the outlining of the bibliographic research, with a description of the methods the bibliography collection and analysis. Section 4 presents and discusses the results, while section 5 is devoted to the final considerations.

\section{THEORETICAL FRAMEWORK}

\subsection{Sustainability in companies}

Sustainability, as an alternative to development, has been gaining prominence in the business and academic world in recent years. Thus, the challenge arises for the companies to incorporate in their management a base that allows to elaborate and to implement socially and environmentally responsible actions, along with the actions guided by the economic objectives.

In the academy, studies that seek to understand the challenge of sustainable management and also contribute to the insertion of sustainability in the company's actions are mainly directed to cases of large companies (BIEDER et al., 2002; SCHALTEGGER; LÜDEKE-FREUND, 2011).

According to Dias (2017), the term sustainability is based on satisfying human needs without compromising future generations and the environment in which one lives.

For Epstein and Roy (2001), organizational sustainability is characterized as a strategic issue, which proposes to balance the social, environmental and economic aspects of the 
DOI: 10.14807/ijmp.v11i1.1002

organization and society. Thus, as shown by Lee and Saen (2012), business sustainability is directly related to the Triple Bottom Line (TBL).

The TBL, according to Milne and Gray (2013), is an understanding that guides sustainability reports with the company's commitment to sustainable development. The incorporation of indicators into management and business reporting has become synonymous with the practice of organizational sustainability. In addition, companies are using strategies based on sustainability as an opportunity to remain competitive (CHANG; CHENG, 2019).

According to Bonacchi and Rinaldi (2007), sustainability requires the translation of the strategy into managerial actions, defined in steps that must be followed to reach the strategic objectives. However, this effort ends up being a great challenge because, as Epstein and Wisner (2001) argue, managers often do not know how to implement sustainability strategies, since these strategies need to be planned and aligned with the company's objectives.

Based on the joint strategy and objectives, companies need management tools that can contribute to the implementation of organizational objectives and their respective strategies based on sustainability (KAPLAN; NORTON, 2004). In this perspective, the traditional Balanced Scorecard (BSC) and the Sustainable Balanced Scorecard (SBSC) are potentially useful to insert sustainability in management and also to contribute to the generation of competitive advantage in companies.

\subsection{Balanced Scorecard}

Kaplan and Norton (2004) developed the Balanced Scorecard (BSC) with the intention of overcoming the corporate challenges of a management that aims to relate the financial sector to the non-financial sectors of the organization. Tsalis et al. (2013) emphasize the BSC as a control system that makes it possible to improve the management of the strategic objectives of the organization, besides allowing proposing corrective actions and improvements.

Bora et al. (2017) understand that the BSC is a tool that is not limited to the control at the corporate strategic level but which can be used in each business unit of the corporation and in each division or department of the business unit. Emphasizing the care needed to maintain strategic alignment among all levels present at the organization’s structure.

In the context of administration, the control function has the mission of daily diagnosing the entire administrative process, evaluating each objective through performance indicators. In this context, the BSC assists the implementation and control process by mapping the strategies, 
DOI: 10.14807/ijmp.v11i1.1002

in an aligned, segmented and specific manner, valuing financial and non-financial control (HANSEN; SCHALTEGGER, 2012; GEORGIEV, 2017).

The implementation of BSC, according to Kaplan and Norton (2004), is divided into three steps:

- First step: clear definition of business objectives and strategies by defining the strategic posture of the company (statement of values, mission, vision and strategic objectives) and the alignment of the specific objectives and guidelines to the defined strategic posture.

- Second stage: review of existing processes, evaluating their adequacy to the company's new strategic posture.

- Third stage: creation of the strategic map, which should highlight the cause and effect relationships between the strategic objectives and the specific objectives and strategies proposed at all levels of the organization.

Belli et al. (2013) describe that for a good implementation of BSC it is imperative that the "What, How, When, How Much, Where and Who" questions are clearly defined and thus help in proposing performance indicators that meet the perspectives of the company's strategic posture.

The BSC is used by many companies in the design and implementation of the corporate strategy, but can also be used in the process of insertion of sustainability throughout the whole company's management (EPSTEIN; WISNER, 2001; OLIVEIRA et al., 2012).

For Belli et al. (2013) the BSC strategic map can be easily adapted in several business models, as it allows for, in the development of the strategic plan, addressing each of the BSC's four perspectives: financial, customer, internal processes and learning/growth.

Falle et al. (2016) add that the BSC translates a company's strategic position into strategic objectives and actions aligned with specific long, medium and short-term objectives, facilitating management by results.

Also, Figge et al. (2002) complement the importance of BSC in the perspective of sustainable management, given that the division and the specificity of the objectives and strategies allow directing sustainable actions proposals in all organizational and administrative processes, starting from the elaboration of the strategic posture. 
ISSN: $2236-269 X$

DOI: 10.14807/ijmp.v11i1.1002

\subsection{Sustainable Balanced Scorecard - SBSC}

The first publications related to BSC and sustainability were presented by Azzone et al. (1996), Elkington (1998), Epstein and Wisner (2001) consider the BSC as a suitable tool to facilitate the integration of sustainability in the management of an organization.

Hansen and Schaltegger (2012) and Silva and Callado (2013) corroborate while affirming that BSC can also be transformed into a specific tool for guiding a company management in sustainability.

Figge et al. (2002) points out that the BSC is modified when sustainability is integrated into its perspectives, shifting to being recognized as SBSC, allowing management and measurement in a specific way within the framework of control of objectives and strategies related to sustainability, in other words, in addition to the financial perspectives, customers, internal processes and learning/growth, the sustainability perspective is included (HANSEN; SCHALTEGGER, 2012).

On the other hand, Schaltegger (2011), Rohm and Montgomery (2011), Sands et al. (2016), point out that SBSC can be considered the basis for a systematic and controlled management of a sustainability-based business involving daily checklists, in addition to allow the alignment between the strategies and principles of the Triple Bottom Line.

Researchers such as Epstein and Wisner (2001), Deegan (2002), Figgie et al. (2001), Butler et al. (2011), suggest three implementations for the SBSC:

a) The integration of environmental and social issues with the four perspectives in the traditional BSC. Sustainability measures should be integrated into all company operations, starting with the main strategy and defining metrics to follow the whole process.

b) Add a fifth perspective, called environmental and social perspective, where the objectives and strategic actions will be particularly directed to.

c) Develop a specific BSC for environmental and social issues, without the involvement of other departments of the company.

Hsu et al. (2011) propose a SBSC structure based on the four BSC perspectives. In which, the financial and customer perspectives have been shifted to the stakeholder perspective and the sustainability perspective. 
DOI: 10.14807/ijmp.v11i1.1002

Hansen and Schaltegger (2012) add that two aspects in structuring the chosen model will be important to characterize the integration of sustainability into the strategy: 1) the way social and environmental objectives are considered in the perspectives adopted, and 2) how the hierarchy of perspectives is drawn (hierarchical process).

Figge et al. (2002) further emphasize that the inclusion of sustainability in the BSC should defend the subordination of all perspectives to the economic perspective, to show that the model is not only a public relations tool but a management tool for business units. That is, as manifested by Chung et al. (2016), the efforts to make business sustainable should aim at creating competitive advantage for companies.

Thus, it is understood that organizational sustainability is a strategic option aligned with the company's main objectives and the search for the balance between social, environmental and economic aspects, as proposed by the Triple Bottom Line (TBL). In this sense, the SBSC will allow to relate to the profitability, customer satisfaction and loyalty, and employee productivity (CHALMETA; PALOMERO, 2011; EPSTEIN; ROY, 2001; LEE; SAEN, 2012; BONACCHI; RINALDI, 2007; HANSEN; SCHALTEGGER, 2012).

\section{METHOD}

The bibliographic research had four stages (Figure 1). In the first stage, the search keywords were defined: "sustainability management", "balanced scorecard" and "small business".

The second stage allowed to define the inclusion and exclusion criteria for the research collection process: a) the keywords can be present in any part of the publication (title, abstract, keywords, text body, references); b) Science Direct and Scielo databases (both databases consulted on 2/08/2018 and 3/01/2019) were chosen, as well as Google Scholar (consulted between Jan 31st, 2018 and Feb 5th, 2018); c) it was considered as publication period from 2000 to March 2019.

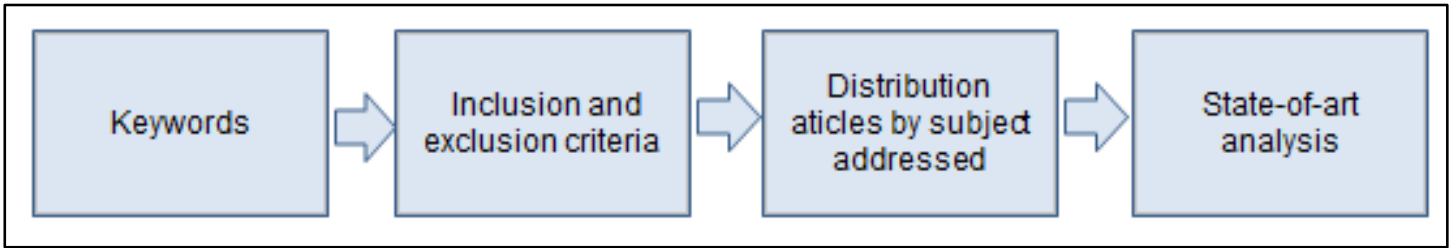

Figure 1: Stages of the research

Source: Prepared by the authors 
DOI: 10.14807/ijmp.v11i1.1002

In the third stage, the articles were distributed according to the type of work and subjects discussed and, in the fourth stage, the state of the art of research on sustainable management, which uses BSC applied to small companies, was analyzed.

\section{RESULTS}

In the Google Scholar, 164 publications were collected, including articles, books, book chapter, reports, course papers, dissertations and doctoral theses, 194 papers were collected at Science Direct. In the Scielo database only four articles were found, all in the Spanish language.

Then, from the articles found, a new collection process was carried out through the references cited by these articles. Papers that addressed the issues related to the search keywords used in the first collection phase were selected. Thus, we selected another 246 articles, collected between February and May 2018 (Table 1).

Table 1: Total documents collected by base

\begin{tabular}{lc}
\hline Scielo & 4 \\
Science Direct & 194 \\
Google acadêmico & 164 \\
Bibliographic references & 246 \\
\hline Grand total & $\mathbf{6 0 8}$ \\
\hline & Source: Prepared by the authors
\end{tabular}

Regarding the types of papers, approximately 75,5\% of the 608 publications collected are articles from international scientific journals, while 24\% are papers published through congresses, journals at university level, master's dissertations and doctoral theses (Table 2).

Table 2: Type of documents

\begin{tabular}{lr}
\hline Bachelor Thesis & 14 \\
Congress & 40 \\
Published reports & 2 \\
Doctor Dissertation & 10 \\
Scientific Journal & 460 \\
Master Dissertation & 22 \\
University magazine & 27 \\
Book & 30 \\
\hline Grand total & $\mathbf{6 0 8}$ \\
\hline
\end{tabular}

Source: Prepared by the authors

As this research aims to show and discuss the state of the art of the researches that relate the keywords used in the bibliographic collection, for the fourth stage, the works with greater relevance and impact in the development of knowledge were selected. Thus, publications such as books, university journals, congresses, course work, master's dissertations and doctoral theses were excluded. The publications in international scientific journals were selected. 
DOI: 10.14807/ijmp.v11i1.1002

It is understood that the types of Works excluded, although they play an important role in the development and discussion of knowledge, have lower impact than the articles published in scientific journals, due both to their lesser diffusion strength and to the lower rigor of evaluation in the publication process.

Recalling that for the fourth stage (analysis of the state of the art) only articles that address the topics sustainable management and BSC; sustainable management and small business; and sustainable management, BSC and small companies will be selected from 463 papers published in scientific journals.

Approximately 92\% of the articles independently addressed each of the keywords considered in the collection of the papers or were related to subjects other than the object of study of this research. Thus, through analysis of the abstracts, 36 publications were selected, distributed as follows: 15 articles (Appendix A) that deal with issues of sustainable management and small business; 17 articles (Appendix B) that address the issues of sustainable management and BSC; and finally 4 articles intersecting sustainable management, BSC and small business (Figure 2).

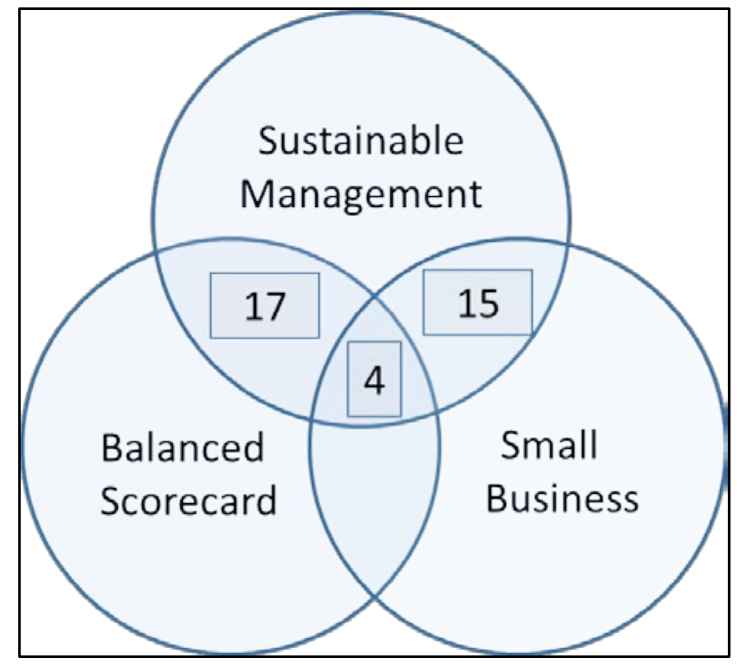

Figure 2: Distribution scheme of collected articles Source: Prepared by the authors

Among the 36 articles selected, 43\% were published by researchers from Germany; 8\% by Greece; 8\% from Australia, 8\% from the United States. Regarding the relevance of the selected papers, $8 \%$ were published in journals that had between 0 and 2 of impact factor (according to the JCR of 2017), 8\% between 2 and 3, 32\% with more than 3 impact factor.

The article with the largest number of citations (1,161 citations) was The Sustainability Balanced Scorecard-Linking Sustainability Management to Business Strategy”, from Frank 
INDEPENDENT JOURNAL OF MANAGEMENT \& PRODUCTION (IJM\&P)

http://www.ijmp.jor.br

v. 11, n. 1, January-February 2020

ISSN: $2236-269 X$

DOI: 10.14807/ijmp.v11i1.1002

Figge; Tobias Hahn; Stefan Schaltegger; Marcus Wagner from the University of Lüneburg, Germany, Center for Sustainability Management, in 2002 in Business Strategy and the Environment, whose impact factor is 5,355.

The publications that intersect the subjects delimited for this research (Fig. 2) are reduced, compared to the total of publications collected (Table 2). Thus, the periodicity of the publications is approximately two publications per year (between 2000 and 2019).

It should be noted that the main country of origin of most publications is Germany, whose researchers belong to the "Centre for Sustainability Management, University of Lüneburg”.

However, when the subject is about research intersecting sustainable management, BSC and small business issues, literature is much more limited, highlighting the signaling gap for future research. In this sense, the last stage of this bibliographic research consists of a qualitative analysis, which aims to characterize the knowledge frontier developed through the 36 selected papers.

\subsection{Analysis of the state of the art}

The analysis was elaborated in three stages, grouping the articles related to each intersection.

\subsubsection{Sustainable management and BSC}

From the 17 articles analyzed, it is understood that BSC is an appropriate tool to implement sustainability in business management. The BSC is also called SBSC and is presented as a functional tool, which links the company's activities to its objectives, taking into account socio-environmental responsibility.

In two articles reservations regarding the implementation of the SBSC were found. For Epstein and Wisner (2001) there are two significant obstacles to implementing sustainability: 1) Lack of managerial knowledge to implement strategies based on sustainability; 2) In the view of managers, actions focused on environmental responsibility often reduce the attractiveness of the business.

In this sense, Epstein and Wisner (2001) conducted a study applied in two large companies that allowed them to develop a cause and effect map to identify the financial effect that can lead to the adoption of a non-financial strategy. (Example: strategies related to employee health and safety). The result showed that developing and implementing the SBSC 
INDEPENDENT JOURNAL OF MANAGEMENT \& PRODUCTION (IJM\&P)

http://www.ijmp.jor.br

v. 11, n. 1, January-February 2020

ISSN: 2236-269X

DOI: 10.14807/ijmp.v11i1.1002

is beneficial to the company because it allows them to develop strategies aligned with their vision and objectives. It will also enable monitoring the strategies through quantifiable indicators, as well as integrating financial and non-financial measures, which are important for measuring performance in a comprehensive manner.

For Bieker and Waxenberger (2002), the BSC is appropriate to integrate environmental and social aspects into the Company's strategic management. However, in practice, they identified that in the traditional use of BSC the financial perspective of companies prevailed, preventing a balanced integration of social and environmental issues.

To solve this problem, Bieker and Waxenberger (2002) proposed the integrity scorecard or ISC, a management system that would meet the demands of all stakeholders in the company's actions. It is an integrative ethical approach that seeks to ensure pluralistic management based on the value demanded by stakeholders. Thus, being able to ensure the operational efficiency of the BSC. In the same line as the authors analyzed, Hansen and Schaltegger (2016) also proposes a conceptual framework of SBSC based on the interests of stakeholders.

Authors such as Figge et al. (2002), Epstein and Wisner (2001), Butler et al. (2011), Bieker and Waxenberger (2002) emphasize the use of SBSC as an appropriate management tool to implement sustainability strategies. However, Bieker and Waxenberger (2002) point out that, because it is an operational tool that aims to link the company's activity to its main objectives, it is possible that the company's performance regarding corporate social responsibility become less evident.

Figge et al. (2002) describe that sustainability management implemented with the SBSC tool helps overcome barriers in other implementation approaches by integrating the sustainability pillars into a single, enterprise-wide management. The authors report that the development stages of a SBSC comply with requirements related to the integration of environmental and social management to the strategic management of the company.

Butler et al. (2011) argue that the use of SBSC will make it possible to clearly see the relationship between sustainable practices, corporate strategies and profitability. That is, as proposed by Rohm and Montgomery (2011), the use of the SBSC will allow aligning the strategies to the principles of TBL.

On the side of the empirical research, Chalmeta and Palomero (2011) elaborated a case study with the objective of improving the SBSC tool, validating the concepts of sustainability and showing its implementation in the company strategies. Schaltegger (2011) and Hsu et al. 
DOI: 10.14807/ijmp.v11i1.1002

(2011) also developed a case study research, aiming to propose the SBSC as the tool that will allow measuring the company's sustainable performance.

Schaltegger and Lüdeke-Freund (2011) have contributed with a survey that suggests that the structure of the SBSC should be aligned with the company's strategic map from a causeand-effect perspective.

Sands et al. (2016) presents an empirical study of large companies in Australia on the feasibility of integrating the social and environmental dimensions into the traditional four dimensions of BSC.

Finally, Hansen and Schaltegger (2016) conducted a systematic review of the literature covering a two-decade period focusing on the measurement and management of sustainability performance. The modifications to the traditional BSC, including the SBSC, have been mapped and characterized as architectures that describe the hierarchy between performance perspectives and strategic objectives, as well as the influence of organizational values.

In general, it can be commented that the analyzed articles enriched the theoretical and applied knowledge about the sustainable management and the use of the tool BSC. The applied researches show the search for the validation of the BSC as a facilitator of the insertion and measurement of sustainability in the companies’ management.

\subsubsection{Sustainable management and small business}

Sustainable management in small enterprises is seen as a process of innovation, given the importance of sustainable development in society (BOS-BROUWERS, 2010; HANSEN; KLEWITZ, 2012; SEBRAE, 2015).

Hansen and Klewitz (2012) conducted a survey analyzing the heterogeneous view between 1987 and 2010 of the studies focused on innovation practices in the area of sustainability, including strategic behaviors and sustainable management in small enterprises. This study reflects the lack of further research focused on sustainability.

On the other hand, Tsai and Chou (2009), Bergeron et al. (2010), Johnson and Schaltegger (2016), Verboven and Vanherck (2015), Ethos-Sebrae (2016), address the use of tools for the sustainability process.

Tsai and Chou (2009) and Bergeron et al. (2010) present a study on ISO 9001, ISO 14001, OHSAS 18001 and SA 8000 systems, contributing to the understanding of the diverse opportunities that small companies have for dealing with resource constraints and to increase 


\section{INDEPENDENT JOURNAL OF MANAGEMENT \& PRODUCTION (IJM\&P)}

http://www.ijmp.jor.br

v. 11, n. 1, January-February 2020

ISSN: 2236-269X

DOI: 10.14807/ijmp.v11i1.1002

their capabilities, given the challenge of sustainable management. ISO 9001 designates technical standards that establish a model of quality management for organizations, regardless of their type and size.

ISO 14001 specifies the requirements of an environmental management system, allowing an organization to develop a framework for environmental protection. The OHSAS 18001 consists of a series of British standards, developed by the BSI Group, to guide the formation of a Management and Certification System for Safety and Occupational Health. SA 8000 is an international standard for the assessment of social responsibility for suppliers and vendors based on conventions from the International Labor Organization.

In the same line of systems evaluated by Tsai and Chou (2009), Bergeron et al. (2010), Johnson and Schaltegger (2016) argue that most of these systems are still poorly implemented in small enterprises. They point to the main barriers to implementation: lack of awareness, lack of perception over the benefits, lack of managerial knowledge and experience, lack of human and financial resources, as well as the difficulties arising from informal structures in small enterprises.

On the other hand, Verboven and Vanherck (2015) and the Ethos-Sebrae (2016) report show that any system or tool aimed at sustainable management will be effective when it brings benefits to the competitiveness of the business and, at the same time, for all stakeholders.

The research on sustainable management and small business also addressed the limitations related to the knowledge and skills that small entrepreneurs have to implement and manage sustainability (JOHNSON, 2017; NAICKER et al., 2017). For these authors, knowledge management is an important tool to strengthen sustainability in practice, since it will make actions more efficient and effective.

Another approach found in the articles collected refers to sustainability as a business strategy (HÖRISCH et al., 2015; SHIELDS; SHELLEMAN, 2015; SUKKAR, 2017).

Hörisch et al. (2015) emphasize that the strategic choice of sustainability will require manager knowledge and the use of tools. In this case, it is possible that company size influences the process, although the empirical research of the authors has shown that the size of the company apparently did not influence the use of sustainable management tools.

Shields and Shelleman (2015) present a tool for the development of sustainable strategies; it is a sustainable SWOT, which aims to facilitate the elaboration of strategies 
DOI: 10.14807/ijmp.v11i1.1002

through the analysis of organizational environments, in order to facilitate the alignment between objectives and strategies.

Sukkar (2017) presents a research on the benefits to companies, including small business, when they implement sustainability since the development of the strategic plan. It considers management tools and indicators for assessing sustainability performance.

Chang and Cheng (2019) developed an integrated multi-attribute decision analysis model to identify key sustainability indicators that play a vital role in boosting the sustainable performance of manufacturing in small and medium-sized enterprises (SMEs).

Therefore, through the researchers analyzed, it can be understood that there is a growing academic discussion about the integration of sustainability in small companies. These surveys present knowledge as an important differential for sustainable management in addition to highlighting that there are few tools used by companies. However, it is understood that there is a need to increase the number of empirical research to expand this discussion.

\subsubsection{Sustainability, BSC and Small Business}

Four articles were found and analyzed. We sought to understand the motivations, objectives and contributions of the research.

Sukkar (2017) was motivated by: the increasing deflation of environmental resources; the importance of socio-environmental responsibility for all business, including small enterprises; as well as the need for sustainable actions to contribute to the competitiveness of small business.

While for Falle et al. (2016) and Medel et al. (2011) the motivations are based on the importance of small companies to the economy, as well as the need to strategically manage sustainability, relying on the SBSC tool. Yet, Tsalis et al. (2013) justifies the research to the lack of empirical evidences that show the use of the SBSC in the development and implementation of sustainable strategies.

As for the objectives proposed by the researches, it is worth mentioning the operationalization of BSC as a tool for sustainable management in small companies. In order to align sustainable actions with company objectives (SUKKAR, 2017), integrates sustainable actions into the management process and BSC (MEDEL et al., 2011), as well as overcome the challenges of implementing sustainable BSC (TSALIS et al., 2013). And, Falle et al. (2016) sought to empirically evaluate the SBSC in the context of small enterprises. 
INDEPENDENT JOURNAL OF MANAGEMENT \& PRODUCTION (IJM\&P)

http://www.ijmp.jor.br

v. 11, n. 1, January-February 2020

ISSN: $2236-269 X$

DOI: $10.14807 /$ ijmp.v11i1.1002

The contributions, from Medel et al. (2011), show the complexity of sustainability in the business environment, especially in small companies. Therefore, the development of strategies based on sustainability and aligned with corporate objectives, paying attention to the implementation and control process, should come along with the communication process, through the use of the Global Reporting Initiative (GRI) report.

Tsalis et al. (2013) show the importance of the environmental analysis, making use of the SWOT tool, for the decision process of the small business managers when adopting the SBSC tool. The article also contributes to the literature review that evaluates the insertion of sustainability in BSC, which resulted in the so-called SBSC.

Falle et al. (2016) through a case study, show the importance of SBSC in the strategic management of sustainability in small companies. There are additional benefits in the use of the tool, such as improving the integration of sustainability in all business activities and establishing priorities, as well as the possibility of identifying new areas of activity.

Sukkar (2017) shows the possibility of a paradigm shift in small companies, facilitating, consequently, the insertion and integration of sustainability in the management and in all the activities of the company. Sustainability in line with the company's reality will improve the control and performance of strategies.

\section{SUSTAINABILITY, BSC AND SMALL BUSINESS FROM BIG DATA PERSPECTIVES}

Aspects of sustainability are becoming more important to supply chain management, making it a challenge as sustainability adds less quantifiable aspects to supply chain management than the classic aspects of the process. On the other hand, measuring sustainability is crucial to the implementation of modern supply chain management (LIEBETRUTH, 2017).

López-Robles et al. (2019) present six thematic areas related to intelligent solutions: Business Intelligence; Innovation and Organizational Performance Management; Data and Decisional Process; Competitive Intelligence and National Intelligence. Among them, the data area and the decision-making process stand out as the most representative in terms of the number of citations in their research. For the authors, this thematic area covers topics related to data, query processing, database management systems, decision trees, visualization of information, transactional data, extraction of information, and analysis of data in real time.

Another area of research using Big Data is innovation management and organizational performance. It is possible to emphasize the growth of the interest in this area of research, due 


\section{INDEPENDENT JOURNAL OF MANAGEMENT \& PRODUCTION (IJM\&P)}

http://www.ijmp.jor.br

v. 11, n. 1, January-February 2020

ISSN: 2236-269X

DOI: 10.14807/ijmp.v11i1.1002

to the rapid growth of the h-index of works such as that of López-Robles et al. (2019). This work shows the opportunity to use the technology to change internal processes, which are time consuming to organize and update the data and the performance indicators, thus making it difficult for a dynamic response from organizations for increasingly complex environments.

López-Robles et al. (2019) highlight a model of intelligence maturity and its application that will attract the interest of the scientific community in the future. They also affirm that small business are being seen in many places as a vital motor for growth, needing to develop and incorporate resources associated with Intelligence; bringing complete improvements to the organization with capabilities to quantify and facilitate its incorporation within organizations.

The need to translate and understand codified information is shown by Pröllochs and Feuerriegel (2018). Associated with the use of the SWOT analysis tool where it is possible to analyze the risks and opportunities of organizational environments, the authors present methods based on advanced analyzes, which can perform all the calculations in a computerized way and, consequently, subsidizing the managers in the update, in the establishment of goals, performance measurement, and assessments with arbitrary frequency.

On the other hand, Marín-Ortega et al. (2014) address Big Data in order to: increase revenue; reduce costs and increase productivity. In this sense, the authors present a business intelligence application model based on Zachman Framework, which considers four lines of the structure: (1) strategy model, (2) business model, (3) system model, and (4) model of technology. Thus, the model proposed by them is composed of components of business architecture, interconnecting the components of business intelligence and relations between them. The model follows seven steps: step 1 - business architecture; step 2 - extract and load processes; step 3 - instrumentalize the management control; step 4 - transformation process; step 5 - virtual data; step 6 - develop the business intelligence system and step 7 - analysis.

Zhou et al. (2018) comment on the use of diffuse technology applied to deal with vague, uncertain and qualitative information, as in the case of sustainable management and the supply chain, or as in the evaluation of recycling partners. A weighting technique is used combining the fuzzy method and the DEMATEL-AEWFVIKOR evaluation.

Thus, it can be said that currently there is no research that relates directly the Big Data and the improvement of strategic management via BSC. However, there are studies that report on intelligent models, using technological solutions based on Big Data that could come to meet BSC, subsidizing the establishment of targets, measurement, analysis and management decision making through risk and organization environment analysis. Consequently, it can be 
DOI: 10.14807/ijmp.v11i1.1002

said that the intersection between BSC, strategic management and sustainability could benefit from the Big Data research.

\section{FINAL CONSIDERATIONS}

The present need of companies to contribute to the sustainable development of society requires more than isolated or departmentalized actions within the organizational structure. The importance of developing an efficient and effective sustainable management is understood, which allows maintaining and, if possible, improving the company's competitiveness, taking into account the needs of stakeholders.

In the case of small companies, sustainable management presents itself as an opportunity, and in the near future even as a requirement, of competitiveness. On the other hand, sustainable management becomes the major administrative challenge, due to the characteristics of small enterprises, where management and administrative functions (planning, organization, direction and control) generally do not follow a formal and professional process. In this sense, the use of management tools, such as the BSC and the SBSC, is essential to allow the operationalization and control of the strategies, as well as align them with the objectives, at all levels of the organizational structure.

The BSC tool is widely used by medium and large companies, proving useful to improve the process of implementation and strategic control, as well as the efficiency of the management of the company as a whole. Also, the BSC received special attention from the researchers, who adapted it to the specific needs of sustainable management, renaming it as SBSC.

However, despite the importance of small business to society and the economy, sustainable management and BSC have not yet received wide attention from the academy, specially when it comes to applied research, which would improve practical knowledge about the use of BSC and the effort to develop sustainable management.

\section{ACKNOWLEDGMENTS}

This study was financed in part by the Coordination of Improvement of Higher Education Personnel - Brazil (CAPES) - Finance Code 001.

\section{REFERENCES}

AKHTAR, P.; KHAN, Z.; FRYNAS, J. G.; TSE, Y. K.; RAO-NICHOLSON, R. (2018) Essential Micro-foundations for Contemporary Business Operations: Top Management Tangible Competencies, Relationship-based Business Networks and Environmental 
DOI: 10.14807/ijmp.v11i1.1002

Sustainability. British Journal Management, v. 29, n. 1, p. 43-62. doi:10.1111/14678551.12233.

AZZONE, G.; NOCI, G.; MANZINI, R.; WELFORD, R.; YOUNG, C. W. (1996) Defining environmental performance indicators: an integrated framework. Business strategy and the environment, v. 5, n. 2, p. 69-80. https://doi.org/10.1002/(SICI)1099-0836(199606).

BELLI, A. P.; ANDRUCHECHEN, J. R.; ALBERTON, L.; PETRI, S. M. (2013) Proposta de implementação do planejamento estratégico e balanced scorecard: um estudo em uma microempresa de manufatura. Revista de estudos contábeis, v. 4, n. 7, p. 57-76.

BERGERON, H.; BOULERNE, S.; ROY, C.; WOLF, D. (2010) Identification des Enjeux Prioritaires des PME dans le but D'établir un Tableau de Bord pour leur Gestion du Développement Durable. Crises et Nouvelles Problématiques de la Valeur, Nice, France. Cd-Rom; 2010.

BIEDER, T.; FRIESE, A.; HAHN, T.; Axel Springer Verlag (2002)

Nachhaltigkeitsmanagement am Druckstandort. In: SCHALTEGGER, S.; DYLLICK, T. (Hrsg.): Nachhaltig managen mit der Balanced Scorecard - Konzept und Fallstudien. Wiesbaden: Gabler, p. 167-198.

BIEKER, T.; WAXENBERGER, B. (2002) Sustainability balanced scorecard and business ethics: Developing a Balanced Scorecard for Integrity Management. In: $\mathbf{1 0}^{\text {th }}$ International Conference of the Greening of Industry Network, Göteborg/Sweden.

BONACCHI, M.; RINALDI, L. (2007) DartBoards and Clovers as new tools in sustainability planning and control. Business Strategy and the Environment, v. 16, n. 7, p. 461-473. https://doi.org/10.1002/bse.596.

BORA, B.; BORAH, S.; CHUNGYALPA, W. (2017) Crafting Strategic Objectives: Examining the Role of Business Vision and Mission Statements. Journal of Entrepreneurship \& Organization Management, v. 6, n. 1, p. 1-6. https://doi: 10.4172/2169-026X.1000205.

BOS-BROUWERS, H. E. J. (2010) Corporate sustainability and innovation in SMEs: Evidence of Themes and Activities in Practice. Business Strategy and the Environment, v. 19, p. 417-435. https://doi.org/10.1002/bse.652.

BUTLER, J. B., HENDERSON, S. C.; RAIBORN, C. (2011) Sustainability and the balanced scorecard: Integrating green measures into business reporting. Management Accounting Quarterly, v. 12, n. 2, p. 1-10.

CANTELE, S.; ZARDINI, A. (2018) Is sustainability a competitive advantage for small businesses? An empirical analysis of possible mediators in the sustainability-financial performance relationship. Journal of Cleaner Production, v. 182, n. 1, p. 166-176. https://doi.org/10.1016/j.jclepro.2018.02.016.

CHALMETA, R.; PALOMERO, S. (2011) Methodological proposal for business sustainability management by means of the Balanced Scorecard. Journal of the Operational Research Society, v. 62, n. 7, p. 1344-1356. https://doi.10.1057/jors.2010.69

CHANG, A; CHENG, Y. (2019) Analysis model of the sustainability development of manufacturing small and medium- sized enterprises in Taiwan. Journal of Cleaner Production, v. 207, p. 458-473. 10.1016/j.jclepro.2018.10.025.

CHUNG, C. C.; CHAO, L. C.; CHEN, C. H.; LOU, S. J. (2016) A Balanced Scorecard of Sustainable Management in the Taiwanese Bicycle Industry: Development of Performance 
DOI: 10.14807/ijmp.v11i1.1002

Indicators and Importance Analysis. Sustainability, v. 8, n. 6, p. 1-21. https://doi:10.3390/su8060518.

DEEGAN, C. (2002) Introduction: the legitimising effect of social and environmental disclosures - a theoretical foundation. Journal Accounting, Auditing e Accountability, v. 15, n. 3, p. 282-311. https://doi.org/10.1108/09513570210435852.

DEPKEN, D.; ZEMAN, C. (2017) Small business challenges and the triple bottom line. TBL: Needs assessment in a Midwest State, USA. Technological Forecasting Social Change.

DIAS, R. (2017) Gestão ambiental: responsabilidade social e sustentabilidade. 3 ed. São Paulo: Atlas.

ELKINGTON, J. (1998) Partnerships from cannibals with forks: The triple bottom line of 21st-century business. Environmental Quality Management, p. 37-51.

https://doi.org/10.1002/tqem.3310080106.

EPSTEIN, M. J.; ROY, M. J. (2001) Sustainability in action: Identifying and measuring the key performance drivers. Long range planning, v. 34, n. 5, p. 585-604.

https://doi.org/10.1016/S0024-6301(01)00084-X.

EPSTEIN, M. J.; WISNER, P. S. (2001) Using a balanced scorecard to implement sustainability. Environmental quality management, v. 11, n. 2, p. 1-10. https://doi.org/10.1002/tqem.1300.

ETHOS-SEBRAE (2016). Indicadores Ethos-Sebrae para micro e pequenas empresas. Instituto Ethos.

FALLE, S.; ORCID, R. R.; ENGERT, S.; BAUMGARTNER, R. J. (2016) Sustainability management with the sustainability balanced scorecard - austrian case study. Sustainability, v. 8, n. 545, p. 1-16. https://doi:10.3390/su8060545.

FIGGIE, F.; HAHN, T.; SCHALTEGGER, S.; WAGNER, M. (2001) The Sustainability Balanced Scorecard - a tool for value oriented sustainability management in strategy-focused organizations. Conference Proceedings of the 2001 ecomanagement and auditing conference. ERP environment, p. 83-90.

FIGGE, F.; HAHN, T.; SCHALTEGGER, S.; WAGNER, M. (2002) The Sustainability Balanced Scorecard - linking sustainability management to business strategy. Business Strategy and the Environment, v. 11, n. 5, p. 269-284. https://doi: 10.1002/bse.339.

GEORGIEV, M. (2017) The Role of the Balanced Scorecard as a Tool of Strategic Management and Control. Journal of Innovations and Sustainability, v. 3, n. 2, p. 31-63.

GIAMA, E.; PAPADOPOULOS, A. M. (2018) Carbon footprint analysis as a tool for energy and environmental management in small and medium-sized enterprises. International Journal of Sustainable Energy, v. 37, n. 1, p. 21-29, doi: 10.1080/14786451.2016.1263198.

HANSEN, E. G.; KLEWITZ, J. (2012) Publicly Mediated Inter-Organizational Networks: A solution for Sustainability Oriented Innovation in SMEs? Entrepreneurship, Innovation and Sustainability, Wagner, M (Ed.), Greenleaf.

HANSEN, E. G.; SCHALTEGGER, S. (2012) Pursuing sustainability with the balanced scorecard: Between shareholder value and multiple goal optimisation. Centre for

Sustainability Management, Working Paper Series, p. 1-35.

http://dx.doi.org/10.2139/ssrn.2169335.

HANSEN, E. G.; SCHALTEGGER, S. (2016) The Sustainability Balanced Scorecard: A Systematic Review of Architectures. Journal of Business Ethics, v. 133, p. 193-221. 
HÖRISCH, J.; JOHNSON, M. P.; SCHALTEGGER, S. (2015) Implementation of Sustainability Management and Company Size: A Knowledge-Based View. Business Strategy and the Environment, v. 24, p. 765-779. https://doi.org/10.1002/bse.1844.

HUBBARD, G. (2009) Measuring organizational performance: beyond the triple bottom line. Business Strategy and the Environment, v. 18, p. 177-191. https://doi.org/10.1002/bse.564.

HSU, C. W.; HU, A. H.; CHIOU, C. Y.; CHEN, T. C. (2011) Using the FDM and ANP to construct a sustainability balanced scorecard for the semiconductor industry. Expert Systems with Applications, v. 38, n. 10, p. 12891-12899. https://doi.org/10.1016/j.eswa.2011.04.082.

JOHNSON, M. P.; SCHALTEGGER, S. (2016) Two Decades of Sustainability Management Tools for SMEs: How Far Have We Come? Journal of Small Business Management, v. 54, n. 2, p. 481-505. https://doi.org/10.1111/jsbm.12154.

JOHNSON, M. P. (2017) Knowledge acquisition and development in sustainability oriented small and medium sized enterprises: Exploring the practices, capabilities and cooperation.

Journal of Cleaner Production, v. 142, n. 4, p. 3769-3781.

https://doi.org/10.1016/j.jclepro.2016.10.087.

KAPLAN, R. S.; NORTON, D. P. (2004) Mapas estratégicos: convertendo ativos intangíveis em resultados tangíveis. São Paulo: Campus.

LEE, K. H.; SAEN, R. F. (2012) Measuring corporate sustainability management: A data envelopment analysis approach. International Journal of Production Economics, v. 140, n. 1, p. 219-226. https://doi.org/10.1016/j.ijpe.2011.08.024.

LIEBETRUTH, T. (2017) Sustainability in Performance Measurement and Management Systems for Supply Chains. Procedia Engineering, v. 192, p. 539-544. https://doi.org/10.1016/j.proeng.2017.06.093.

LÓPEZ-ROBLES, J. R.; OTEGI-OLASO, J. R.; PORTO GÓMEZ I.; COBO, M. J. (2019) 30 years of intelligence models in management and business: A bibliometric review.

International Journal of Information Management, v. 48, p. 22-38.

https://doi.org/10.1016/j.ijinfomgt.2019.01.013.

MARÍN-ORTEGA, P. M.; DMITRIYEV, V.; ABILOV, M.; MARX GÓMEZ, J. (2014)

ELTA: New Approach in Designing Business Intelligence Solutions in Era of Big Data. Procedia Technology, v. 16, p. 667-674. https://doi.org/10.1016/j.protcy.2014.10.015.

MEDEL, F.; GARCÍA, L.; ENRIQUEZ, S.; ANIDO, M. (2011) Reporting models for corporate sustainability in SMEs. In: Golinska, P. M; Fertsch; Marx-Gómez, J. (Eds.), Information technologies in environmental engineering, Heidelberg: Springer, p. 407-418. http://doi: 10.1007/978-3-642-19536-5_32.

MILNE, M. J., GRAY, R. (2013) W(h)ither ecology? The triple bottom line, the global reporting initiative, and corporate sustainability reporting. Journal of business ethics, v. 118, n. 1, p. 13-29.

NAICKER, V.; LE ROUX, S.; BRUWER, J.; BRUWER, J. P. (2017) Knowledge Sharing as a Value-Adding Initiative for South African SMME Sustainability: A Literature Review.

Expert Journal of Business and Management, v. 5, n. 2, p. 51-60.

NAWAZ, W.; KOÇ, M. (2018) Development of a systematic framework for sustainability management of organizations. Journal of Cleaner Production, v. 171, n. 10, p.1255-1274. https://doi.org/10.1016/j.jclepro.2017.10.011. 
OLIVEIRA, L. R.; MEDEIROS, R. M.; TERRA, P. B.; QUELHAS; O. L. G. (2012) Sustentabilidade: da evolução dos conceitos à implementação como estratégia nas organizações. Production, v. 22, n. 1, p. 70-82. http://dx.doi.org/10.1590/S010365132011005000062.

PRÖLLOCHS, N.; FEUERRIEGEL, S. (2018) Business analytics for strategic management: Identifying and assessing corporate challenges via topic modeling. Information \& Management. https://doi.org/10.1016/j.im.2018.05.003

ROHM, H.; MONTGOMERY, D. (2011) Sustainability to Corporate Strategy Using the Balanced Scorecard. The Balanced Scorecard Institute: Cary, NC, USA.

SANDS, J. S.; RAE, K. N.; GADENNE, D. (2016) An empirical investigation on the links within a sustainability balanced scorecard (SBSC) framework and their impact on financial performance. Accounting Research Journal, v. 29, n. 2, p. 154-178.

https://doi.org/10.1108/ARJ-04-2015-0065.

SCHALTEGGER, S. (2011) Sustainability as a driver for corporate economic success: consequences for the development of sustainability management control. Society and Economy, v. 33, n. 1, p. 15-28.

SCHALTEGGER, S.; LÜDEKE-FREUND, F. (2011) The Sustainability Balanced Scorecard. Concept and the Case of Hamburg Airport; Leuphana Universität Lüneburg: Lüneburg, Germany.

SEBRAE - Centro Sebrae de Sustentabilidade (2015) Sustentabilidade nos Pequenos Negócios, 2 ed.; Cuiabá-Sebrae.

SEBRAE - Serviço Brasileiro de Apoio às Micro e Pequenas Empresas (2018) Análise do CAGED. Brasília-DF.

SHIELDS, J.; SHELLEMAN, J. M. (2015) Integrating sustainability into SME strategy. Journal of Small Business Strategy, v. 25, n. 2, p. 59-75.

SILVA, M. D. O. P.; CALLADO A. A. C. (2013) Análise de Modelos de Balanced Scorecard elaborados a partir da ótica da Sustentabilidade através do uso da Matriz SWOT.

Administração, Contabilidade e Sustentabilidade, v. 3, n. 4, p. 87-103. https://doi.org/10.18696/reunir.v3i4.175.

SUKKAR, A. E. (2017) Sustainability: Its Factors and its Performance Evaluation. Journal of Commerce and Educational Thoughts, v. 1, p. 14-30.

http://doi.org/10.26476/jcet.2017.01.14-30.

TSAI, W. H.; CHOU, W. C. (2009) Selecting management systems for sustainable development in SMEs: A novel hybrid model based on DEMATEL, ANP, and ZOGP. Expert Systems with Applications, v. 36, n. 2, p. 1444-1458. https://doi.org/10.1016/j.eswa.2007.11.058.

TSALIS, T. A.; NIKOLAOU, I. E.; GRIGOROUDIS, E.; TSAGARAKIS, K. P. (2013) A framework development to evaluate the needs of SMEs in order to adopt a sustainabilitybalanced scorecard. Journal of Integrative Environmental Sciences, v. 10, n. 3-4, p. 179197. https://doi.org/10.1080/1943815X.2013.858751.

VERBOVEN, H.; VANHERCK, L. (2015) Sustainability as a management process for SMEs: Analysis of existing tools in Flanders and best-of-breed proposal.

Schwerpunktthema, v. 23, n. 4, p. 241-249. 
ISSN: 2236-269X

DOI: 10.14807/ijmp.v11i1.1002

ZHOU, F.; WANG, X.; LIM, M. K.; HE, Y.; LI, L. (2018) Sustainable recycling partner selection using fuzzy DEMATEL-AEW-FVIKOR: A case study in small-and-medium enterprises (SMEs). Journal of Cleaner Production, v. 196, p. 489-504. https://doi.org/10.1016/j.jclepro.2018.05.247.

\section{Appendix A}

Publications selection: intersection Sustainable Management and BSC

\begin{tabular}{|c|c|c|c|c|c|}
\hline Source & Title & Author & $\begin{array}{c}\text { Publication } \\
\text { Year }\end{array}$ & Affiliation & Country \\
\hline $\begin{array}{l}\text { Environmental Quality } \\
\text { Management }\end{array}$ & $\begin{array}{l}\text { Using a Balanced Scorecard to } \\
\text { Implement Sustainability. }\end{array}$ & $\begin{array}{l}\text { MJ Epstein; PS } \\
\text { Wisner }\end{array}$ & 2001 & $\begin{array}{l}\text { Jones Graduate School of } \\
\text { Management, Rice University, } \\
\text { Houston, Texas }\end{array}$ & USA \\
\hline $\begin{array}{l}10^{\text {th }} \text { International Conference } \\
\text { of the Greening of Industry } \\
\text { Network, Göteborg/Sweden. }\end{array}$ & $\begin{array}{l}\text { Sustainability balanced scorecard } \\
\text { and business ethics: Developing a } \\
\text { balanced scorecard for integrity } \\
\text { management. }\end{array}$ & $\begin{array}{l}\text { T Bieker; B } \\
\text { Waxenberger }\end{array}$ & 2002 & $\begin{array}{l}\text { University of St. Gallen. } \\
\text { Switzerland }\end{array}$ & Switzerland \\
\hline $\begin{array}{l}\text { Business Strategy and the } \\
\text { Environment }\end{array}$ & $\begin{array}{l}\text { Evaluating Environmental and } \\
\text { Social Performance of Large } \\
\text { Portuguese Companies: A } \\
\text { Balanced Scorecard Approach. }\end{array}$ & $\begin{array}{l}\text { I Dias-Sardinha; L } \\
\text { Reijnders }\end{array}$ & 2005 & $\begin{array}{l}\text { Guest Professor, University of } \\
\text { Lisbon, ISEG, SOCIUS }\end{array}$ & Portugal \\
\hline Journal of Industrial Ecology & $\begin{array}{l}\text { The sustainability balanced } \\
\text { scorecard as a framework for eco- } \\
\text { efficiency analysis. }\end{array}$ & $\begin{array}{l}\text { Andreas } \\
\text { Möller;Stefan } \\
\text { Schaltegger }\end{array}$ & 2005 & $\begin{array}{l}\text { Faculty of Environmental } \\
\text { Sciences University of } \\
\text { Lueneburg } 21332 \text { Lueneburg, } \\
\text { Germany }\end{array}$ & Germany \\
\hline $\begin{array}{l}\text { Journal of Accounting \& } \\
\text { Organizational Change }\end{array}$ & $\begin{array}{l}\text { Integrative management of } \\
\text { sustainability performance, } \\
\text { measurement and reporting. }\end{array}$ & $\begin{array}{l}\text { Stefan Schaltegger; } \\
\text { Marcus Wagner }\end{array}$ & 2006 & $\begin{array}{l}\text { Centre for Sustainability } \\
\text { Management, University of } \\
\text { Lüneburg, Germany }\end{array}$ & Germany \\
\hline $\begin{array}{l}\text { Business Strategy and the } \\
\text { Environment }\end{array}$ & $\begin{array}{l}\text { Measuring organizational } \\
\text { performance: Beyond the triple } \\
\text { bottom line. }\end{array}$ & Graham Hubbard & 2009 & $\begin{array}{l}\text { Adelaide Graduate School of } \\
\text { Business, The University of } \\
\text { Adelaide, Australia }\end{array}$ & Australia \\
\hline $\begin{array}{l}\text { Management Accounting } \\
\text { Quarterly }\end{array}$ & $\begin{array}{l}\text { Sustainability and the balanced } \\
\text { scorecard: Integrating green } \\
\text { measures into business reporting. }\end{array}$ & $\begin{array}{l}\text { JB Butler; SC } \\
\text { Henderson; C } \\
\text { Raiborn }\end{array}$ & 2011 & $\begin{array}{l}\text { Professor of Accounting, Texas } \\
\text { State University }\end{array}$ & USA \\
\hline $\begin{array}{l}\text { Journal of the Operational } \\
\text { Research Society }\end{array}$ & $\begin{array}{l}\text { Methodological proposal for } \\
\text { business sustainability } \\
\text { management by means of the } \\
\text { Balanced Scorecard. }\end{array}$ & $\begin{array}{l}\text { R. Chalmeta; S. } \\
\text { Palomero }\end{array}$ & 2011 & $\begin{array}{l}\text { Grupo Integración y Re- } \\
\text { Ingenierı'a de Sistemas (IRIS), } \\
\text { UniversitatJaume I, } 12071 \\
\text { Castellón, Spain }\end{array}$ & Spain \\
\hline Balanced Scorecard Institute & $\begin{array}{l}\text { Link sustainability to corporate } \\
\text { strategy using the balanced } \\
\text { scorecard. Cary, NC: Balanced } \\
\text { Scorecard Institute. }\end{array}$ & $\begin{array}{l}\text { Dan Montgomery; } \\
\text { Howard Rohm }\end{array}$ & 2011 & $\begin{array}{l}\text { Balanced Scorecard Institute } \\
\text { (North Carolina) USA }\end{array}$ & USA \\
\hline Society and Economy & $\begin{array}{l}\text { Sustainability as a driver for } \\
\text { corporate economic success. } \\
\text { Consequences for the } \\
\text { development of sustainability } \\
\text { management control. }\end{array}$ & Stefan Schaltegger & 2011 & $\begin{array}{l}\text { Centre for Sustainability } \\
\text { Management, University of } \\
\text { Lüneburg, Germany }\end{array}$ & Germany \\
\hline $\begin{array}{l}\text { Centre for Sustainability } \\
\text { Management }\end{array}$ & $\begin{array}{l}\text { The Sustainability Balanced } \\
\text { Scorecard: Concept and the Case } \\
\text { of Hamburg Airport. }\end{array}$ & $\begin{array}{l}\text { Florian Lüdeke- } \\
\text { Freund; Stefan } \\
\text { Schaltegger }\end{array}$ & 2011 & $\begin{array}{l}\text { Centre for Sustainability } \\
\text { Management, University of } \\
\text { Lüneburg, Germany }\end{array}$ & Germany \\
\hline $\begin{array}{l}\text { Wseas transactions on } \\
\text { environment and } \\
\text { development }\end{array}$ & $\begin{array}{l}\text { Dynamic Balanced Scorecard: } \\
\text { Model for Sustainable Regional. }\end{array}$ & $\begin{array}{l}\text { Kozena Marcela; } \\
\text { StriteskaMichaela; } \\
\text { SvobodaOndrej }\end{array}$ & 2011 & $\begin{array}{l}\text { Faculty of Economics and } \\
\text { Administration University of } \\
\text { Pardubice Studentska 84, } 532 \\
\text { 10, Pardubice CZECH } \\
\text { REPUBLIC }\end{array}$ & RepublicCzech \\
\hline
\end{tabular}


INDEPENDENT JOURNAL OF MANAGEMENT \& PRODUCTION (IJM\&P)

http://www.ijmp.jor.br

v. 11, n. 1, January-February 2020

ISSN: 2236-269X

DOI: 10.14807/ijmp.v11i1.1002

\begin{tabular}{|l|l|l|l|l|} 
Ecological Indicators & $\begin{array}{l}\text { Development of a sustainable } \\
\text { balanced scorecard framework. }\end{array}$ & $\begin{array}{l}\text { LoannisE.Nikolaou; } \\
\text { Thomas A.Tsalis }\end{array}$ & 2013 & $\begin{array}{l}\text { Department of Environmental } \\
\text { Engineering, Democritus } \\
\text { University of Thrace, Vas } \\
\text { Sofias 12, Xanthi 67100, } \\
\text { Greece }\end{array}$ \\
\hline Journal of Business Ethics & $\begin{array}{l}\text { The Sustainability Balanced } \\
\text { Scorecard: A Systematic Review } \\
\text { of Architectures. }\end{array}$ & $\begin{array}{l}\text { Erik G. Hansen; } \\
\text { Stefan Schaltegger }\end{array}$ & 2016 & $\begin{array}{l}\text { Innovation Incubator and } \\
\text { Centre for Sustainability } \\
\text { Management (CSM)Leuphana } \\
\text { University of } \\
\text { LüneburgLüneburgGermany }\end{array}$ \\
\hline $\begin{array}{l}\text { Accounting Research } \\
\text { Journal }\end{array}$ & $\begin{array}{l}\text { An empirical investigation on the } \\
\text { links within a sustainability } \\
\text { balanced scorecard (SBSC) } \\
\text { framework and their impact on } \\
\text { financial performance. }\end{array}$ & John Stephen Sands & 2016 & $\begin{array}{l}\text { Leuphana University } \\
\text { Lüneburg, Centre for } \\
\text { Sustainability Management, } \\
\text { Scharnhorststraße 1, 21335 } \\
\text { Lüneburg, Germany }\end{array}$ \\
\hline
\end{tabular}

\section{Appendix B}

Publications selection: intersection Sustainable Management and Small Business

\begin{tabular}{|c|c|c|c|c|c|}
\hline Source & Title & Author & $\begin{array}{l}\text { Publicat } \\
\text { ion } \\
\text { Year }\end{array}$ & Affiliation & Country \\
\hline $\begin{array}{l}\text { Business Strategy } \\
\text { and the Environment }\end{array}$ & $\begin{array}{l}\text { Corporate sustainability and } \\
\text { innovation in SMEs: Evidence of } \\
\text { themes and activities in practice. }\end{array}$ & $\begin{array}{l}\text { Hilke Elke } \\
\text { Jacke Bos- } \\
\text { Brouwers }\end{array}$ & 2010 & $\begin{array}{l}\text { VU University } \\
\text { Amsterdam, Faculty } \\
\text { of Economics, } \\
\text { Business } \\
\text { Administration and } \\
\text { Econometrics - VU- } \\
\text { CfE, Amsterdam, } \\
\text { The Netherlands }\end{array}$ & Germany \\
\hline $\begin{array}{l}\text { Expert Systems with } \\
\text { Applications }\end{array}$ & $\begin{array}{l}\text { Selecting management systems for } \\
\text { sustainable development in SMEs: A } \\
\text { novel hybrid model based on } \\
\text { DEMATEL, ANP, and ZOGP. }\end{array}$ & $\begin{array}{l}\text { Wen-Hsien } \\
\text { Tsai; Wen } \\
\text { Chin Chou }\end{array}$ & 2009 & $\begin{array}{l}\text { Department of } \\
\text { Business } \\
\text { Administration, } \\
\text { National Central } \\
\text { University, Jhongli, } \\
\text { Taoyuan 320, } \\
\text { Taiwan, ROC }\end{array}$ & Taiwan \\
\hline $\begin{array}{l}\text { Journal Crises et } \\
\text { nouvelles } \\
\text { problématiques de la } \\
\text { Valeur }\end{array}$ & $\begin{array}{l}\text { Identification des Enjeux Prioritaires } \\
\text { des PME dans le but D'établir un } \\
\text { Tableau de Bord pour leur Gestion du } \\
\text { Développement durable Crises et } \\
\text { Nouvelles Problématiques de la } \\
\text { Valeur. }\end{array}$ & $\begin{array}{l}\text { Hélène } \\
\text { Bergeron; } \\
\text { Sandrine } \\
\text { Boulerne; } \\
\text { Chantal } \\
\text { Roy; } \\
\text { Dominique } \\
\text { Wolff } \\
\end{array}$ & 2010 & $\begin{array}{l}\text { Universidade de } \\
\text { Québec . UQTR - } \\
\text { Universitédu Québec } \\
\text { à Trois-Rivières. } \\
\text { Canada }\end{array}$ & Canada \\
\hline $\begin{array}{l}\text { Entrepreneurship, } \\
\text { Innovation and } \\
\text { Sustainability }\end{array}$ & $\begin{array}{l}\text { Publicly mediated inter-organizational } \\
\text { networks a solution for sustainability } \\
\text { oriented innovation in SMEs. }\end{array}$ & $\begin{array}{l}\text { Erik G. } \\
\text { Hansen; } \\
\text { Johanna } \\
\text { Klewitz }\end{array}$ & 2012 & $\begin{array}{l}\text { Leuphana University } \\
\text { Lüneburg, } \\
\text { Scharnhorststraße 1, } \\
\text { D-21335 Lüneburg, } \\
\text { Germany }\end{array}$ & Germany \\
\hline $\begin{array}{l}\text { Seminário } \\
\text { internacional sobre } \\
\text { pequenos negócios }\end{array}$ & $\begin{array}{l}\text { Inovação e sustentabilidade, bases } \\
\text { para o futuro dos pequenos negócios. }\end{array}$ & $\begin{array}{l}\text { Realização: } \\
\text { Sebrae }\end{array}$ & 2012 & Sebrae & Brazil \\
\hline
\end{tabular}


INDEPENDENT JOURNAL OF MANAGEMENT \& PRODUCTION (IJM\&P)

http://www.ijmp.jor.br

v. 11, n. 1, January-February 2020

ISSN: 2236-269X

DOI: 10.14807/ijmp.v11i1.1002

\begin{tabular}{|c|c|c|c|c|c|}
\hline $\begin{array}{l}\text { Corporate Social } \\
\text { Responsibility and } \\
\text { Environmental } \\
\text { Management }\end{array}$ & $\begin{array}{l}\text { Sustainability Management and Small } \\
\text { and Medium-Sized Enterprises: } \\
\text { Managers' Awareness and } \\
\text { Implementation of Innovative Tools. }\end{array}$ & $\begin{array}{l}\text { Matthew P. } \\
\text { Johnson }\end{array}$ & 2013 & $\begin{array}{l}\text { LeuphanaUniversität } \\
\text { Lüneburg, Centre for } \\
\text { Sustainability } \\
\text { Management (CSM), } \\
\text { Lüneburg, Germany }\end{array}$ & Germany \\
\hline $\begin{array}{l}\text { Journal of Cleaner } \\
\text { Production }\end{array}$ & $\begin{array}{l}\text { Sustainability-oriented innovation of } \\
\text { SMEs: A systematic review. }\end{array}$ & $\begin{array}{l}\text { Johanna } \\
\text { Klewitz; } \\
\text { Erik G. } \\
\text { Hansen }\end{array}$ & 2014 & $\begin{array}{l}\text { Leuphana University } \\
\text { Lüneburg, } \\
\text { Scharnhorststraße 1, } \\
\text { D-21335 Lüneburg, } \\
\text { Germany }\end{array}$ & Germany \\
\hline $\begin{array}{l}\text { Business Strategy } \\
\text { and the Environment }\end{array}$ & $\begin{array}{l}\text { Implementation of Sustainability } \\
\text { Management and Company Size: A } \\
\text { Knowledge-Based View. }\end{array}$ & $\begin{array}{l}\text { Jacob } \\
\text { Hörisch; } \\
\text { Matthew P. } \\
\text { Johnson; } \\
\text { Stefan } \\
\text { Schaltegger }\end{array}$ & 2015 & $\begin{array}{l}\text { LeuphanaUniversität } \\
\text { Lüneburg, Centre for } \\
\text { Sustainability } \\
\text { Management (CSM), } \\
\text { Lüneburg, Germany }\end{array}$ & Germany \\
\hline $\begin{array}{l}\text { Journal of Small } \\
\text { Business } \\
\text { Management }\end{array}$ & $\begin{array}{l}\text { Two Decades of Sustainability } \\
\text { Management Tools for SMEs: How } \\
\text { Far Have We Come? }\end{array}$ & $\begin{array}{l}\text { Matthew P. } \\
\text { Johnson; } \\
\text { Stefan } \\
\text { Schaltegger }\end{array}$ & 2016 & \begin{tabular}{l|} 
LeuphanaUniversität \\
Lüneburg, Centre for \\
Sustainability \\
Management (CSM), \\
Lüneburg, Germany
\end{tabular} & Germany \\
\hline $\begin{array}{l}\text { Journal of Small } \\
\text { Business Strategy }\end{array}$ & $\begin{array}{l}\text { Integrating sustainability into sme } \\
\text { strategy. }\end{array}$ & $\begin{array}{l}\text { Jeff Shields; } \\
\text { Joyce M. } \\
\text { Shelleman }\end{array}$ & 2015 & $\begin{array}{l}\text { University of North } \\
\text { Carolina, Ashville. } \\
\text { USA }\end{array}$ & USA \\
\hline Schwerpunktthema & $\begin{array}{l}\text { Sustainability as a management } \\
\text { process for SMEs: Analysis of } \\
\text { existing tools in Flanders and best-of- } \\
\text { breed proposal. }\end{array}$ & $\begin{array}{l}\text { Hans } \\
\text { Verboven; } \\
\text { Lise } \\
\text { Vanherck }\end{array}$ & 2015 & $\begin{array}{l}\text { Universiteit } \\
\text { Antwerpen } \\
\text { AntwerpenBelgium. }\end{array}$ & Belgium \\
\hline $\begin{array}{l}\text { Journal of Cleaner } \\
\text { Production }\end{array}$ & $\begin{array}{l}\text { Knowledge acquisition and } \\
\text { development in sustainability oriented } \\
\text { small and medium sized enterprises: } \\
\text { Exploring the practices, capabilities } \\
\text { and cooperation. }\end{array}$ & $\begin{array}{l}\text { Matthew P. } \\
\text { Johnson }\end{array}$ & 2017 & $\begin{array}{l}\text { Leuphana University } \\
\text { Lüneburg, Centre for } \\
\text { Sustainability } \\
\text { Management, } \\
\text { Scharnhorststraße 1, } \\
21335 \text { Lüneburg, } \\
\text { Germany } \\
\end{array}$ & Germany \\
\hline Instituto Ethos & $\begin{array}{l}\text { Indicadores Ethos-Sebrae para micro } \\
\text { e pequenas empresas }\end{array}$ & $\begin{array}{l}\text { Realização: } \\
\text { Instituto } \\
\text { Ethos de } \\
\text { empresas e } \\
\text { responsabili } \\
\text { dade social }\end{array}$ & 2016 & $\begin{array}{l}\text { Instituto Ethos- } \\
\text { Sebraae }\end{array}$ & Brazil \\
\hline $\begin{array}{l}\text { Journal of business } \\
\text { and management }\end{array}$ & $\begin{array}{l}\text { Knowledge Sharing as a Value- } \\
\text { Adding Initiative for South African } \\
\text { SMME Sustainability: A Literature } \\
\text { Review. }\end{array}$ & $\begin{array}{l}\text { Visvanathan } \\
\text { Naicker; } \\
\text { Suzaan Le } \\
\text { Roux; Juan } \\
\text { Bruwer; } \\
\text { Juan-Pierré } \\
\text { Bruwer } \\
\end{array}$ & 2017 & $\begin{array}{l}\text { Cape Peninsula } \\
\text { University of } \\
\text { Technology, South } \\
\text { Africa }\end{array}$ & $\begin{array}{l}\text { South } \\
\text { Africa }\end{array}$ \\
\hline $\begin{array}{l}\text { Journal of Cleaner } \\
\text { Production }\end{array}$ & $\begin{array}{l}\text { Analysis model of the sustainability } \\
\text { development of manufacturing small } \\
\text { and medium- sized enterprises in } \\
\text { Taiwan. }\end{array}$ & $\begin{array}{l}\text { Chang, A; } \\
\text { Cheng, Y. }\end{array}$ & 2019 & $\begin{array}{l}\text { National Formosa } \\
\text { University, Taiwan }\end{array}$ & Taiwan \\
\hline
\end{tabular}

